\title{
A-IV-12 重症僧帽弁狭窄症の手術適応と成績
}

\begin{tabular}{|c|c|c|c|c|c|}
\hline \multirow[b]{2}{*}{ 小机 敏昭 } & \multicolumn{3}{|c|}{ 東京慈恵会医科大学 心臓外科 } & \multirow[b]{2}{*}{ 中野 } & \multirow[b]{2}{*}{ 雅道 } \\
\hline & 堀越 茂樹 & 鈴木 & 茂 & & \\
\hline 佐々木達海 & 宮沢 総 & 益子 & 健男 & 古川 & \\
\hline & 森田紀代 & 新井 & 達太 & & \\
\hline
\end{tabular}

左心機能低下および三尖弁閉鎖不全 (TR) を合併する 重症僧帽弁狭窄症 (MS) 症例の手術成績は, 従来不満足 なものであった．しかし，近年，術前・術中・術後管理 の進歩・発展に伴い，その手術成績が，めざましく向上 してきた。そこで今回は，重症 MS 症例の手術適応と 成績を述へ，教室での手術成績向上のための対策につき 報告する。

\section{対 象}

1972 年から 1983 年 12 月までの, 教室における血行 動態上有意の逆流を持たないMS 手術症例数は 281 例 である.このらち, 重症 MS として, 術前 LVEF 0.45 以下, 心俰数 $2.00 \mathrm{l} / \mathrm{min} / \mathrm{m}^{2}$ 以下の左心機能低下例, 肺 高血圧を伴う TR 合併症例を選ぶと，33 例が該当する. 33 例のらちわけは, 左心機能低下群 15 例, TR 合併群 18 例である.

\section{手術適応}

手術適応汇関しては, 術前のらっ血性心不全のコント ロールを充分に行った上で手術することが重要なポイン トである. 術前 2 週間以上の入院安静治療を行い, CTR・ 胸水貯溜・肝腫大・PVC・総ビリルビン值・Ccrなど, らっ血性心不全に伴ら症状の改善をみた所で手術を行う
ようにしている。とく， PVC 頻発例, 総ビリルビン 值 $2.0 \mathrm{mg} / \mathrm{d} l$ 以上, $\operatorname{Ccr} 30 \mathrm{~m} l / \mathrm{min}$ 以下の症例の予後 は悪く, 術前の厳重な管理が必要である.

\section{手術成樍}

左心機能低下群 15 例の早期死は 1 例 $(6.7 \%)$, TR 合併群 18 例の早期死は 2 例 (11\%) で, 重症 MS 以外 の MS 症例の早期死 $1.2 \%(\mathrm{CMC} 46(0) \cdot \mathrm{OMC} 179$ (1)・MVR 13(2)) に比し, 高率であった. なお, 重症 MS の早期死 3 例の原因は，いずれも LOS であった.

次に，手術法別に検討すると表 1 のごとくで，MVR. MVR+TAP または TVR で術後 LOS の発生率が高 く，とくに TR を伴う症例では，去の死亡率も高い。 LOS の発生原因は術前の心機能低下のみならず，重症 MS 33 例中, CMC 後の再手術症例 11 例 $(33 \%)$, 左 房内血栓 12 例 $(36 \%)$ とその頻度が高く, このため, 手術操作が複雑化し，手術時間が長くなることも誘因に なっている．をた，MVR 飞使用した人工弁で成績を比 ベると，Björk-Shiley 拈ょび SJM の機械弁を使用した 時期に 3 例の死亡がみられ，Ionescu-Shiley 弁を使用し た 1980 年以後は，死亡がみられない。

術後 LOS 群・非 LOS 群の術前肺機能・腎機能・肝 機能・心内圧および心機能を比較し, 多少とも有意差が

表 $1<$ 年度別手術成績 $>$

\begin{tabular}{lccccccc}
\hline \multirow{2}{*}{ 手 術 法 } & \multicolumn{3}{c}{$1973 \sim 1979$} & \multicolumn{3}{c}{$1980 \sim 1983$} \\
\cline { 2 - 7 } & 症例数 & LOS & 早期死 & 症例数 & LOS & 早期死 \\
\hline MVR & 6 & 2 & 1 & 6 & 2 & 0 \\
MVR+TAP & 2 & 2 & 1 & 1 & 0 & 0 \\
MVR+TVR & 1 & 1 & 1 & 1 & 1 & 0 \\
\hline OMC & 0 & - & - & 3 & 1 & 0 \\
OMC+TAP & 9 & 0 & 0 & 2 & 0 & 0 \\
OMC+TVR & 2 & 0 & 0 & 0 & - & - \\
\hline \multicolumn{1}{c}{ 計 } & 20 & 5 & $3(15 \%)$ & 13 & 4 & $0(0 \%)$ \\
\hline
\end{tabular}



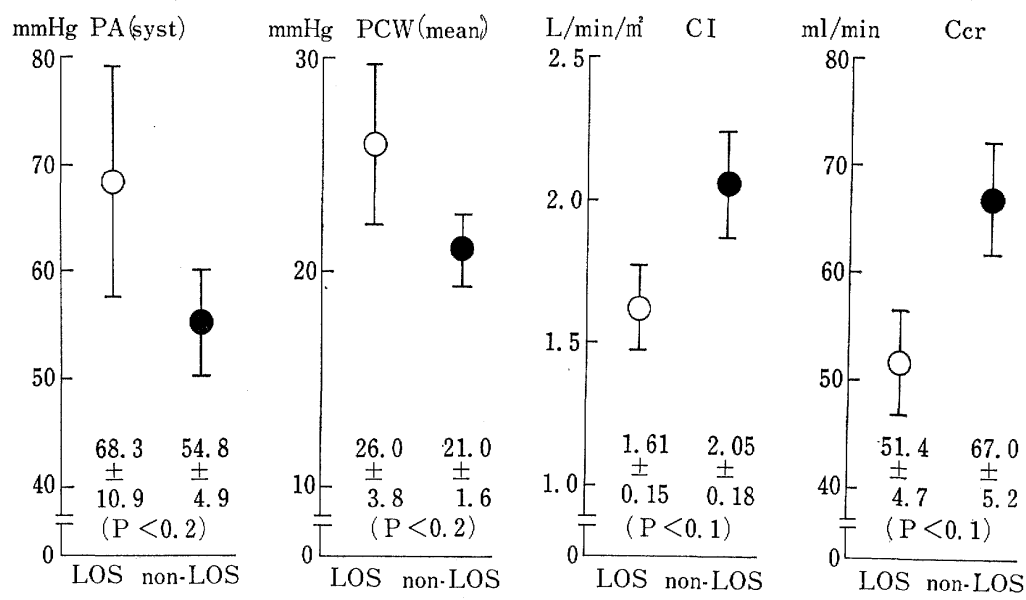

図 1 術後 $\operatorname{LOS}$ 群・non-LOS 群の術前検査データの比較 $($ mean $\pm S E)$

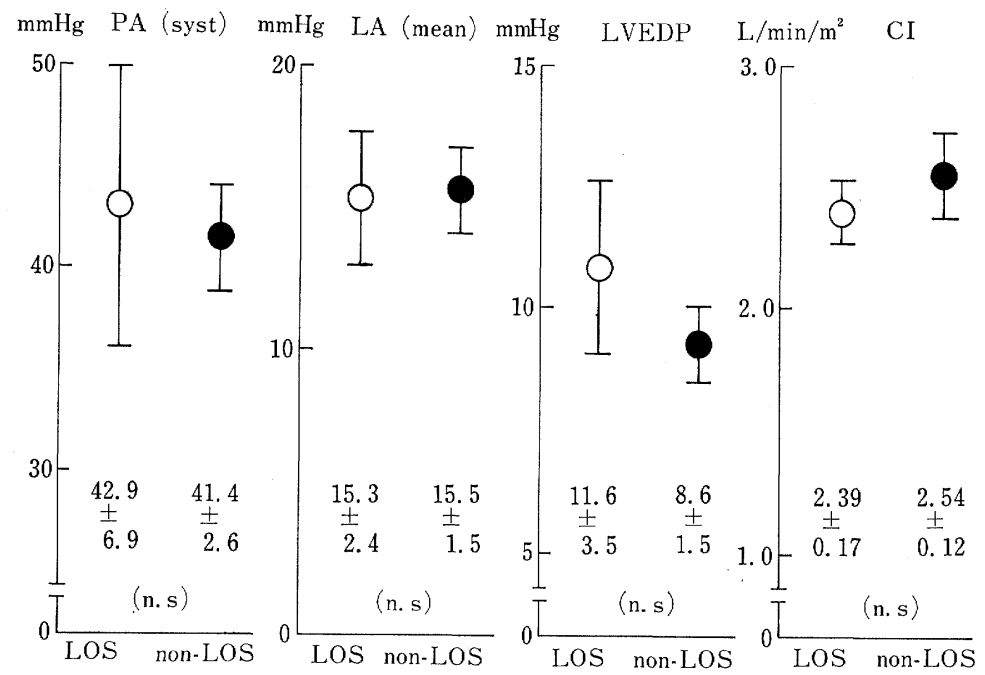

図 2 LOS 治療群と non-LOS 群の心内圧と心係数の比較 (mean士SE)

みられたデータを示すと（図 1)，LOS 群で肺動脈収縮 期圧 (PA syst) ・ 肺動脈楔入部平均圧 (PCW mean) が 高值を示し，心係数 $(\mathrm{CI}) \cdot \mathrm{Ccr}$ が低值を示した. これ らの検查值は, 術後の LOS 発生を予想する上飞, 重要 な意味をもち，術前異常值がみられた症例では，IABP を stand by し，いっでも使える態勢をとっている.

LOS 発生例では, IABP・カテコールアミン・血管拡 張剤を早期に使用することとしている。 この結果を図 2 に示す。 これらの治療により, LOS 群の術後 PAsyst ・ 左房平均圧 (LA mean) - LVEDP . CI は, 非 LOS 群 と同程度の数值まで改善している.

\section{考案}

教室における手術成績向上の対策を示す。

（1）術前管理：手術適応の項で述べたごとく，うっ血 性心不全の強力な治療が必要である.

（2）術中管理：LOS が予測される症例に対する 麻酔 導入時・CPB 離脱時からの IABP 使用は有効で, 心筫 保護法の習熟, Ionescu-Shiley 弁の使用之共に，手術成 績向上沉役立っている.

（3）術後管理上，LOS の早期発見は重要で，IABP • カテュールアミン・血管拡張剤の早期使用は躊躇なく行 
っている，また，呼吸管理の向上も見逃せない．

結語

以上の対策により手術成績注向上した。 1973〜79 年 の重症 MS 20 例中, LOS 発生 5 例, 早期死 3 例 (15
\%) 飞対し，1980 年以後 13 例中 4 例の LOS 発生をみ たが，早期死は 1 例もみられず，遠隔成績も良好である。

文 献 1）小机敏昭洼か：日胸外会誌 $31: 480,1983$.

\section{A-IV-13 重症僧帽弁狭窄症の手術適応と成績}

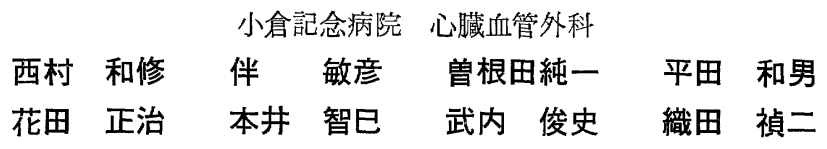

重症嘼帽弁狭窄症のうち，三尖弁閉鎖不全合併例を対 象として，その手術成績と手術の危険因子を検討し，成 績向上への刘策について発表する.

\section{対象と方法}

1974 年より現在むでに行われた，三尖弁疾患を合併し た MS，または MSR の患者 114 例を対象とした。 ま ず，症例を cardioplegia 導入を境として前後期に分け， 病院死亡率と死因の差を検討した. 次に, 後期 67 例を IABP を使用した群 (I 群) と非使用群 (II 群) 飞分け $\tau$, その心肺機能 (PAm, RVEDP, Pcw, LVEDP, CI, $\mathrm{CTR}, \% \mathrm{VC}, \mathrm{FEV})$, 及び栄養状態々肝腎機能 (\% NI, Bil, chE, chol, BUN, Cr, Ccr, レニン活性, アルドステ ロン)の各值について比較検討した。ささらに，I群を子 防的 IABP 使用群 (I a 群) と非予防的使用群 (I b 群）に分けて，各指標につき同様に比較検討した．予防 的使用は, 原則として体外循環開始直後よりパンピング を始めて扮り，その設定基準は，次の通りとした，i） Ccr $40 \mathrm{~m} l / \mathrm{min}$ 以下, Bil $2.0 \mathrm{mg} / \mathrm{d} l$ 以上のらちいずれ か 1 つ. ii ) Ccr $45 \mathrm{~m} l / \mathrm{min}$ 以下, Bil $1.0 \mathrm{mg} / \mathrm{d} l$ 以上, CI $2.0 \mathrm{l} / \mathrm{min} / \mathrm{m}^{2}$ 以下, $\% \mathrm{NI}-20$ 以下，アルドステロン $300 \mathrm{pg} / \mathrm{m} l$ のうち 3 項目以上.

\section{結果}

\section{i）手術成績と死因}

対象例全部の 手術成績は，14/114（病院死亡率 12.3 \%) で, Cardioplegia 導入前後では, 前期 7/47 (同 $14.9 \%$ ), 後期 $7 / 67$ (同 10.4\%) と若干の成績向上をみ たにとどまった（表 1)．前後期の死因を検討すると，
表 1 Cardioplegia 導入前後での成績の比較

\begin{tabular}{lll}
\hline & 前 期 (死亡率) & 後 期 \\
\hline OMC+TAP & $0 / 5$ & $0 / 5$ \\
MVR + TAP & $2 / 20(10 \%)$ & $1 / 30(3.3 \%)$ \\
MVR + TVR & $3 / 4(75 \%)$ & $0 / 0$ \\
OMC+AVR+TAP & $0 / 0$ & $0 / 1$ \\
MVR +AVR+TAP & $2 / 14(14.3 \%)$ & $5 / 25(20 \%)$ \\
MVR +AVR +TVR & $0 / 4$ & $1 / 6(16.7 \%)$ \\
\hline & $7 / 14(14.9 \%)$ & $7 / 67(10.4 \%)$ \\
\hline
\end{tabular}

前期では左室破裂, delayed cardiac tamponade など手 術手技, 術後管理の誤りによるものが 4 例あったが，後 期ではなかった. LOS や腎不全による死亡は前期 3 例, 後期 5 例で, cardioplegia 導入にもかかわらず，後期 に LOS 死が多いのは重症例が増加したためと思われる。

\section{ii ) I 群と II 群の比較}

I 群 27 例, II 群 40 例で I 群のうち 7 例が病院死し た。 心肺機能では PAm, RVEDP がI群で高かった(い ずれも $\mathrm{p}<0.01$ ). LVEDP は有意差こそないもののI 群で高い傾向にあった（表 2). 栄養状態と肝腎機能に ついては\% NI, chE, Ccr がI 群で低く, アルドステロ ンがI群で高かった（表 2).

iii) $\mathrm{I}$ a 群と I b 群との比較

I a 14 例, I b 13 例で病院死亡率はとれぞれ，7.1\%， 46. $1 \%$ でI a 群の方が良好な成績であった $(\mathrm{p}<0.05)$. 術前 NYHA 分類は $\mathrm{I}$ a で $I I{ }^{\circ} 10, \mathrm{IV}^{\circ} 4$, I b では $I^{\circ} 2$, III ${ }^{\circ} 6, \mathrm{IV}^{\circ} 5$ で差はなかった，各指標の有意差検定では\% NI がI a 群で低かったのを除きすずて有意差は認め られなかった（表 3 ). 